\title{
Root Distribution of Different Grapevine Rootstocks on a Relatively Saline Soil*
}

\author{
J.M. Southey
}

Nietvoorbij Institute for Viticulture and Oenology (Nietvoorbij), Private Bag X5026, 7599 Stellenbosch, Republic of South Africa

Submitted for publication: November 1991

Accepted for publication: February 1992

Key words: Grapevine, rootstocks, root distribution, salinity

\begin{abstract}
Distribution of roots of Chenin blanc grafted onto 10 different rootstocks on a relatively saline, sandy clayloam with a varying electrical resistance was investigated. Root distribution was similar for all cultivars in that the majority of roots were found in the shallower soil layers $(<600 \mathrm{~mm})$, where electrical resistance was relatively high. Restriction of root growth in the deeper soil layers appeared to enhance growth of particularly the finer roots, closer to the soil surface. Root number varied with rootstock cultivar, the highest root numbers being found with 216/3 Castel and 1103 Paulsen and the lowest with US 16-13-23 and Ramsey. Above-ground growth and root density of the rootstocks were found to be in balance.
\end{abstract}

In order to elucidate the aerial behaviour of different graft combinations on different soils, it is necessary to study their root systems. The spatial root distribution of the grapevine is believed to be largely determined by the soil environment, either as a consequence of the physical characteristics (Saayman, 1982; Richards, 1983; Van Zyl, 1984; Van Huyssteen, 1988a), chemical properties (Marcelin, 1974; Conradie, 1983), or phytosanitary status (De Klerk \& Loubser, 1988) of the soil. Therefore, any practice which influences the soil environment will affect root distribution (Saayman \& Van Huyssteen, 1980; Van der Westhuizen, 1980; Soyer et al., 1984; Van Huyssteen, 1988b).

The subterranean growth of the grapevine is in balance with its aerial growth (Richards, 1983; Van Zyl \& Van Huyssteen, 1984; Southey \& Archer, 1988; Swanepoel \& Southey, 1989). It can thus be anticipated that any aspect which affects the growth of the roots will affect the aboveground performance of the vine.

Within the confines of a given soil environment, differences in root distribution between different genetic entities have been reported, both with respect to the scion (Daulta \& Chauhan, 1980; Rangelov, Todorov \& Georgiev 1981) and the rootstock cultivar (Branas, 1974; Perry, Lyda \& Bowen, 1983; Swanepoel \& Southey, 1989). Southey \& Archer (1988) concluded that spatial root distribution is largely a function of the soil environment, while root density is predominantly determined by the genetic entity.

The growth of all parts of the grapevine is reduced by salinity to a greater or lesser extent, depending on the cultivar (Groot Obbink \& Alexander, 1973; West \& Taylor, 1984; Downton, 1985; Arbabzadeh \& Dutt, 1987). The rootstocks 216/3 Castel, 1103 Paulsen and 101-14 Millardet et de Grasset are regarded as being more tolerant to salinity than 99 Richter, 110 Richter, 140 Ruggeri and Grezot 1 (Galet, 1979; Pongracz, 1983; Kriel, 1985). In a trial in the same location but with Colombard grafted onto different rootstocks, high yields and vigorous growth were obtained with 13-5 E.V.E. Jerex, Ramsey and 140 Ruggeri, while US 16-13-23 performed poorly (Southey \& Jooste, 1991).

Although the performance of different graft combinations under saline conditions is well researched, discrepancies are still apparent and little is known with respect to root performance. The aim of this study was, therefore, to quantify the soil environment and establish to what extent the genetic entity affects the rooting pattern.

\section{MATERIALS AND METHODS}

Soil: The soil on which the trial was planted occurs widely on the lower river terraces of the Breede River Valley $(33,46 \mathrm{~S}, 19,50 \mathrm{E})$ and is classified as being of the Oakleaf form as described by MacVicar et al. (1977). This soil is characteristically a dark, reddish brown, sandy clayloam with a well developed crumb structure.

Prior to preparation of the soil, it was sampled at depths of $0-300 \mathrm{~mm}, 300-600 \mathrm{~mm}$ and $600-900 \mathrm{~mm}$ and analysed with respect to particle size distribution, $\mathrm{pH}(\mathrm{KC} 1)$, electrical resistance (saturated paste), electrical conductivity (saturation extract) and cations, using standard Nietvoorbij analytical techniques. The soil was prepared by delving to a depth of $600 \mathrm{~mm}$ and 1,0 $\mathrm{t}$ of superphosphate (10,5\% P) was applied per ha. After nine years and at different stages throughout the tenth growing season, the electrical resis-

* Part of a M.Sc. Agric. thesis to be submitted to the University of Stellenbosch

Acknowledgements: The assistance of staff of the Wine Grapes, Soil Science and Plant Protection sections of Nietvoorbij is acknowledged. In particular, the author wishes to thank staff of the Robertson Experimental Farm for their help with the preparation of soil profiles as well as G.W. Fouche, J.J. Hunter, H.C. Strauss, Antoinette Lourens and Stephnie van Zyl for their technical assistance. 
tance was determined at depths of $0-250 \mathrm{~mm}, 250-500$ $\mathrm{mm}, 500-750 \mathrm{~mm}$ and $750-1000 \mathrm{~mm}$. Bulk density of the profiles was determined using the core method (Blake, 1965).

The methods described by De Klerk (1970; 1978), Marais (1983) and Loubser (1985) were used to evaluate the phytosanitary status of the soil with respect to the occurrence of phylloxera, margarodes, Phytophtora cinnamomi and nematodes respectively.

Experimental vineyard: The study was conducted in a nine-year-old Vitis vinifera L. cv. Chenin blanc (clone: SN 1061) vineyard grafted onto different rootstock cultivars (Table 1). Details of the experimental vineyard and cultivation practices were reported in an earlier publication (Southey \& Jooste, 1991).

Root studies: Root studies were carried out just prior to the ninth growing season. two representative vines per treatment (rootstock cultivar), selected on the basis of comparable pruning masses in the preceding season, trunk diameters, cordon lengths and diameters, as well as the absence of visible symptoms of disease, were used for the root studies. A trench 1,3 m deep and 1,3 m long was dug parallel to the vine row and $400 \mathrm{~mm}$ from each selected vine and the roots were exposed for a length of $100 \mathrm{~mm}$. Roots were plotted using the profile wall method (Böhm, 1979) and were classified according to the system described by Southey \& Archer (1988).

\section{RESULTS AND DISCUSSION}

Soil characteristics: Particle size and chemical analyses of the soil samples prior to planting are given in tables $2 \mathrm{a}$ and $2 \mathrm{~b}$.

At this stage, the soil had an exchangeable sodium percentage (ESP) of less than 15, an electrical conductivity $\left(\mathrm{EC}_{\mathrm{e}}\right)$ of more than $400 \mathrm{mS} / \mathrm{m}$ (saturation extract) and a $\mathrm{pH}$ of less than 8,5 to a depth of $300 \mathrm{~mm}$ (Table 2b), and could therefore be classified as a saline soil (Richards et al., 1954). The ESP and $\mathrm{EC}_{\mathrm{e}}$, however, increased with depth.

TABLE 1

Genetic origin and clone numbers of the rootstock cultivars studied.

\begin{tabular}{|c|c|c|}
\hline Rootstock Cultivar & Clone & Genetic Origin \\
\hline 13/5 E.V.E. Jerex & $66-03-08$ & Vitis Berlandieri Planch. \\
\hline 216/3 Castel & $66-02-01$ & 1616 C. [Solonis (V. riparia \\
\hline & & $\begin{array}{l}\text { Mich. } \times V . \text { rupestris Sch.) } \times V \text {. } \\
\text { candicans } \text { Engel. }] \times V \text {.riparia. }\end{array}$ \\
\hline Grezot 1 & GZ1 & 1616 C. $\times$ V.rupestris. \\
\hline $101-14 \mathrm{Mgt}$ & AA25 & $V$. rupestris $\times$ V.riparia. \\
\hline 1103 Paulsen & PS28 & V. Berlandieri $\times$ V.rupestris. \\
\hline Ramsey & $\mathrm{SC} 18$ & V. Champini Planch. \\
\hline 99 Richter & RY13 & $V$. Berlandieri x $V$.rupestris. \\
\hline 110 Richter & RQ28 & $V$. Berlandieri $\times V$.rupestris. \\
\hline 140 Ruggeri & RU354 & $V$. Berlandieri $\times$ V.rupestris. \\
\hline US $16-13-23$ & - & 1202 C. (V. vinifera L. x $V$. \\
\hline & & rupestris) x 99 Richte \\
\hline
\end{tabular}

TABLE 2a

Mean particle size analysis and bulk densities of the Oakleaf soil in the experimental vineyard at Robertson.

\begin{tabular}{|l|c|c|c|c|c|c|}
\hline \multirow{2}{*}{$\begin{array}{l}\text { Depth } \\
(\mathrm{mm})\end{array}$} & Clay & Silt & \multicolumn{3}{|c|}{ Sand } & \\
\cline { 2 - 7 } & $\begin{array}{c}<, 002 \mathrm{~mm} \\
(\%)\end{array}$ & $\begin{array}{c}0,002-0,02 \mathrm{~mm} \\
(\%)\end{array}$ & $\begin{array}{c}\text { Fine } \\
0,02-0,2 \mathrm{~mm} \\
(\%)\end{array}$ & $\begin{array}{c}\text { Medium } \\
0,2-0,5 \mathrm{~mm} \\
(\%)\end{array}$ & $\begin{array}{c}\text { Coarse } \\
0,5-2,0 \\
(\%)\end{array}$ & $\begin{array}{c}\text { Bulk }^{1} \\
\text { Density } \\
\left(\mathrm{kg} / \mathrm{m}^{3}\right)\end{array}$ \\
\hline $0-300$ & 21,32 & 15,91 & 49,91 & 9,95 & 2,91 & 1405 \\
$300-600$ & 20,42 & 14,97 & 51,93 & 9,69 & 2,99 & 1423 \\
$600-900$ & 23,87 & 12,86 & 49,47 & 9,96 & 3,50 & 1443 \\
$900-1200$ & - & - & - & - & - & 1484 \\
\hline
\end{tabular}

1 Determined after nine years.

TABLE $2 b$

Chemical analysis of the soil in the experimental vineyard prior to planting of the vineyard.

\begin{tabular}{|c|c|c|c|c|c|c|c|c|c|c|c|c|}
\hline \multirow[t]{2}{*}{$\begin{array}{l}\text { Depth } \\
(\mathrm{mm})\end{array}$} & \multirow[t]{2}{*}{$\mathrm{pH}^{1}$} & \multirow[t]{2}{*}{$\begin{array}{l}\text { Resistance }^{2} \\
\quad(0 \mathrm{hms})\end{array}$} & \multirow[t]{2}{*}{$\begin{array}{c}\mathrm{ECe} \\
(\mathrm{mS} / \mathrm{m})\end{array}$} & \multirow[t]{2}{*}{$\begin{array}{c}\mathrm{P}^{3} \\
(\mathrm{ppm})\end{array}$} & \multirow[t]{2}{*}{$\begin{array}{c}\mathrm{K}^{3} \\
(\mathrm{ppm})\end{array}$} & \multicolumn{4}{|c|}{$\begin{array}{l}\text { Total Extractable Cations } 4 \\
\text { (m.e. } / 100 \mathrm{~g})\end{array}$} & \multirow[t]{2}{*}{$\begin{array}{c}\text { Exchangeable } \\
\text { Sodium } \\
\text { (m.e. } / 100 \mathrm{~g})\end{array}$} & \multirow[t]{2}{*}{$\mathrm{CEC}^{5}$} & \multirow[t]{2}{*}{$\mathrm{ESP}^{6}$} \\
\hline & & & & & & K & $\mathrm{Na}$ & $\mathrm{Ca}$ & $\mathrm{Mg}$ & & & \\
\hline $0-300$ & 7,6 & 437 & 404 & 64 & 311 & 1,16 & 1,44 & 20,97 & 6,60 & 0,81 & 10,37 & 7,55 \\
\hline $300-600$ & 7,8 & 241 & 635 & 13 & 109 & 0,48 & 3,21 & 26,50 & 6,31 & 2,54 & 8,10 & 31,32 \\
\hline $600-900$ & 7,8 & 235 & 647 & 2 & 46 & 0,33 & 3,75 & 34,47 & 9,37 & 3,61 & 6,63 & 54,45 \\
\hline
\end{tabular}

1. $1 \mathrm{M} \mathrm{KC1}$.

2. Measured on the saturated paste in a standard USDA cup.
3. Bray No. 2.

4. $1 \mathrm{M} \mathrm{NH}_{4} \mathrm{Cl}$.

5. Cation exchange capacity (m.e./100g).
6. Exchangeable sodium percentage (\% of $\mathrm{CEC}$ ). 
Characteristically, excessive soluble salts are easily leached from these soils (Richards et al., 1954) and this would be reflected in changing electrical resistance. The latter was found to have increased from planting until the time of the root study (Tables $2 \& 3$ ). This indicates that soluble salts were effectively leached from the upper soil layers with subsequent irrigations.

\section{TABLE 3}

Variation in electrical resistance of an Oakleaf soil in the experimental vineyard at Robertson after nine years and during the tenth growing season.

\begin{tabular}{|l|c|c|c|c|}
\hline \multirow{2}{*}{$\begin{array}{l}\text { Depth } \\
\text { (mm) }\end{array}$} & \multicolumn{4}{|c|}{ Resistance (Ohms) } \\
\cline { 2 - 5 } & \multirow{2}{*}{$\begin{array}{c}\text { After } \\
\text { years }^{2}\end{array}$} & \multicolumn{3}{|c|}{ 10th Growing Season } \\
\cline { 3 - 5 } & Mean & Maximum & Minimum \\
\hline $0-250$ & 1048 & 435 & 632 & 339 \\
$250-500$ & 742 & 358 & 482 & 271 \\
$500-750$ & 497 & 273 & 354 & 191 \\
$750-1000$ & 245 & 273 & 414 & 167 \\
\hline
\end{tabular}

1. Measured on the saturated paste in a standard USDA soil cup.

2. Measured at the time of the root study at the end of the rainy season.

The electrical resistance of the soil was highest at the time of the root study conducted at the end of the rainy season but decreased again during the following growing season (Table 3). During the latter period, intervals between irrigations were extended by approximately one week, which resulted in a greater drying out of the soil (data not shown). These results suggest that the upper soil layers could potentially become salinised if leaching by irrigation is reduced.

The electrical resistance of the deeper soil layers $(>500 \mathrm{~mm})$ remained relatively low and was comparable to that at which visible symptoms of salinity can be expected to occur on the grapevine (Saayman, 1981), while that of the shallower layers $(<500 \mathrm{~mm})$ was generally higher than the arbitrary value of $300 \mathrm{ohms}$. Since no other unfavourable soil chemical conditions and nutrient deficiencies were identified with the soil analyses, the upper soil layer can be regarded as being of a high potential for viticulture, provided that there is sufficient irrigation to leach the excess salts and cultivation practices to minimise salt build-up are followed.

No soil-borne pathogens and pests, which may have affected the numbers of roots, were found in the soil.

Root distribution: The majority of roots (approximately $77 \%$ ), irrespective of rootstock cultivar, were confined to a depth of approximately $600 \mathrm{~mm}$ (Table 4).

Since grapevine roots have been found to penetrate to depths greater than $800 \mathrm{~mm}$ (Richards, 1983; Champagnol, 1984; Van Huyssteen, 1988a), one can conclude that the upper soil layers $(<500 \mathrm{~mm})$ were more favourable for root growth, as a consequence of either the physical or chemical characteristics, which might have been brought about by soil preparation to this depth. The bulk densities of the deeper soil layers $(>600 \mathrm{~mm}$ ) were higher than those to a depth of $600 \mathrm{~mm}$ (Table 2a). However, they were not so high as to restrict root growth (approximately $1700 \mathrm{~kg} / \mathrm{m}^{3}$ ) (Van Huyssteen, 1988a), which suggests that root growth may have been restricted either by poor aeration or unfavourable chemical conditions as indicated by the relatively low electrical resistances and low phosphate concentrations in these deeper layers (Tables 2 and 3). These results suggest that the spatial root distribution is predominantly a function of the soil environment; this is in agreement with the findings of Van Zyl (1984) and Southey \& Archer (1988).

In this study, a higher percentage of roots were found closer to the soil surface $(<200 \mathrm{~mm})$ (Table 4$)$ than in root studies conducted on soils where vertical root growth was not restricted (Southey \& Archer, 1988; Swanepoel \& Southey, 1989). On average 23,7\% of the roots of 1103 Paulsen, 99 Richter, 140 Ruggeri, 110 Richter, 13/5 E.V.E. Jerex and 101-14 Mgt were found to a depth of $200 \mathrm{~mm}$ (Table 4), whereas, for example, in a soil with minimal restrictions to vertical root growth, only $10,3 \%$ of the roots of the same cultivars occurred at this depth (Swanepoel \& Southey, 1989).

Furthermore, although not quantified, greater numbers of roots were observed in the shallower layers between the rows than were found in root studies conducted elsewhere (Southey \& Archer, 1988; Swanepoel \& Southey, 1989). According to Soyer et al. (1984) and Van Huyssteen (1988b) favourable conditions in the topsoil created by minimum and no tillage did not lead to shallower rooting. However, where vertical root growth was impeded by soil compaction, shallower rooting was enhanced (Saayman \& Van Huyssteen, 1980; Van Huyssteen, 1988a). Thus it appears that where vertical distribution is restricted, either physically or chemically, horizontal distribution is enhanced and the upper soil layers are colonised to a greater extent. Conversely, Archer \& Strauss (1985) found that when horizontal root growth was restricted by the proximity of other grapevine roots, vertical distribution was enhanced.

The shallower soil layers, i.e. to a depth of $200 \mathrm{~mm}$, were predominantly colonised by fine roots $(\varnothing<2 \mathrm{~mm})$, while the number of thick roots $(\varnothing>2 \mathrm{~mm})$ remained relatively low (Table 5).

The number of thick roots was highest at depths of 200$600 \mathrm{~mm}$, where $57,8 \%$ of all thick roots were found. Van Zyl (1984) quantified the root system by means of the ratio of fine to thick roots (termed the rooting index) and argued that favourable soil conditions would result in a higher proportion of fine roots and, therefore, a higher rooting index. Using the rooting index as a reflection of the rooting pattern, it was found to be highest to a depth of $200 \mathrm{~mm}$ in the majority of rootstocks and tended to decrease with increasing depth (Fig. 1). Conversely, in a physically similar soil with no restrictions to vertical root growth to a depth of $1000 \mathrm{~mm}$, Van Zyl (1984) found that the rooting index was lowest in the upper soil $(0-250 \mathrm{~mm})$ and increased with depth. These results suggest that for the soil in this study the growth of fine roots was reduced in the deeper soil layers.. 
TABLE 4

Root distribution calculated as a percentage of the total root number of different rootstocks on an Oakleaf soil at Robertson.

\begin{tabular}{|l|r|r|r|r|r|r|}
\hline \multirow{2}{*}{ Rootstock } & \multicolumn{5}{|c|}{ Depth (mm) } \\
\cline { 2 - 6 } Cultivar & $0-200$ & $200-400$ & $400-600$ & $600-800$ & $800-1000$ & $1000-1200$ \\
\hline 216/3 Castel & 19,40 & 31,40 & 26,70 & 12,60 & 6,30 & 3,60 \\
1103 Paulsen & 23,19 & 31,89 & 17,98 & 12,24 & 9,64 & 5,08 \\
99 Richter & 26,00 & 30,96 & 20,56 & 9,09 & 7,05 & 5,94 \\
140 Ruggeri & 13,40 & 29,75 & 31,57 & 14,31 & 7,92 & 3,05 \\
110 Richter & 19,29 & 32,65 & 34,49 & 5,92 & 1,47 & 4,18 \\
13/5 E.V.E. Jerex & 25,10 & 28,40 & 17,80 & 11,30 & 10,20 & 7,16 \\
$101-14$ Mgt & 35,13 & 25,93 & 24,13 & 10,63 & 1,67 & 2,51 \\
Grezot 1 & 28,55 & 28,55 & 24,97 & 13,02 & 3,35 & 1,55 \\
US 16-13-23 & 20,34 & 22,50 & 16,49 & 13,60 & 12,50 & 14,60 \\
Ramsey & 18,85 & 34,17 & 29,75 & 9,43 & 5,15 & 2,65 \\
\hline
\end{tabular}

TABLE 5

Numbers of fine $(\varnothing<2 \mathrm{~mm})$ and thick $(\varnothing>2 \mathrm{~mm})$ roots counted on the profile wall, of different rootstocks at different depths in an Oakleaf soil.

\begin{tabular}{|c|c|c|c|c|c|c|c|c|c|c|c|c|}
\hline \multirow{2}{*}{$\begin{array}{l}\text { Rootstock } \\
\text { cultivar }\end{array}$} & \multicolumn{12}{|c|}{ Depth (mm) } \\
\hline & \multicolumn{2}{|c|}{$0-200$} & \multicolumn{2}{|c|}{$200-400$} & \multicolumn{2}{|c|}{$400-600$} & \multicolumn{2}{|c|}{$600-800$} & \multicolumn{2}{|c|}{$800-1000$} & \multicolumn{2}{|c|}{$1000-1200$} \\
\hline Root class & $<2 \mathrm{~mm}$ & $2 \mathrm{~mm}$ & $<2 \mathrm{~mm}$ & $2 \mathrm{~mm}$ & $<2 \mathrm{~mm}$ & $>2 \mathrm{~mm}$ & $<2 \mathrm{~mm}$ & $2 \mathrm{~mm}$ & $<2 \mathrm{~mm}$ & $>2 \mathrm{~mm}$ & $<2 \mathrm{~m}$ & $2 \mathrm{~mm}$ \\
\hline 216/3 Castel & 273 & 8 & 434 & 23 & 377 & 12 & 173 & 10 & 88 & 4 & 51 & 3 \\
\hline 1103 Paulsen & 261 & 9 & 353 & 23 & 190 & 18 & 149 & 10 & 139 & 12 & 67 & 4 \\
\hline 99 Richter & 268 & 12 & 312 & 21 & 208 & 13 & 91 & 8 & 71 & 5 & 59 & 5 \\
\hline 140 Ruggeri & 122 & 10 & 269 & 24 & 304 & 7 & 138 & 3 & 72 & 2 & 28 & 2 \\
\hline 110 Richter & 184 & 5 & 297 & 20 & 360 & 15 & 57 & 4 & 34 & 3 & 38 & 3 \\
\hline 13/5 E.V.E. Jerex & 251 & 27 & 204 & 27 & 139 & 9 & 95 & 9 & 83 & 5 & 58 & 3 \\
\hline $101-14 \mathrm{Mgt}$ & 288 & 6 & 196 & 21 & 192 & 12 & 83 & 6 & 13 & 1 & 19 & 3 \\
\hline Grezot 1 & 236 & 7 & 223 & 12 & 199 & 10 & 105 & 4 & 26 & 2 & 10 & 3 \\
\hline US $16-13-23$ & 153 & 16 & 166 & 21 & 123 & 14 & 107 & 6 & 100 & 4 & 118 & 3 \\
\hline Ramsey & 127 & 3 & 212 & 18 & 199 & 5 & 62 & 2 & 30 & 3 & 16 & 2 \\
\hline
\end{tabular}

The rooting pattern of 13/5 E.V.E. Jerex, US 16-13-23 and 140 Ruggeri differed from that of the other rootstocks in that the rooting indices of these rootstocks were lowest in the shallowest soil layer $(<200 \mathrm{~mm})$ and increased with increasing depth (Fig. 1). The former two rootstocks had relatively high numbers of thick roots in the shallowest soil layer, with relatively fewer fine roots (Table 5 ). In a soil with few restrictions to root growth, 13/5 E.V.E. Jerex was also found to have a relatively high number of thick roots closer to the soil surface (Swanepoel \& Southey, 1989); this suggests that this phenomenon might be an inherent characteristic of this rootstock. Conversely, the low rooting index of 140 Ruggeri was due to the relatively low number of fine roots in the upper soil layer. 


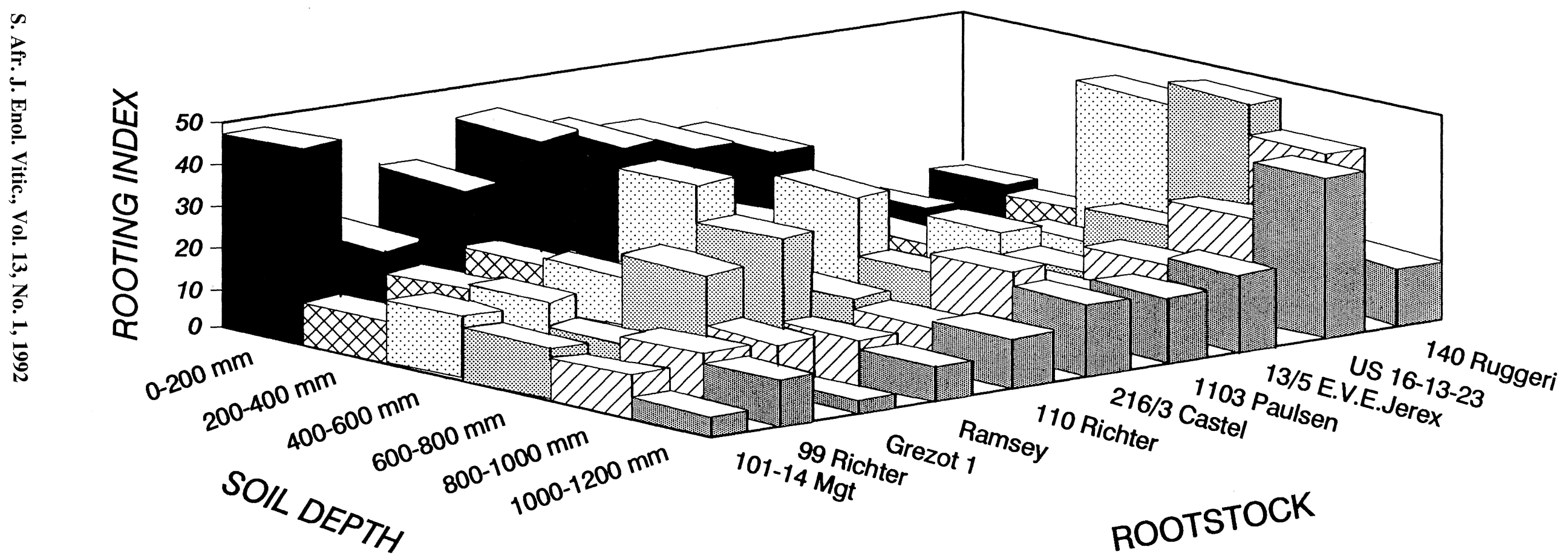




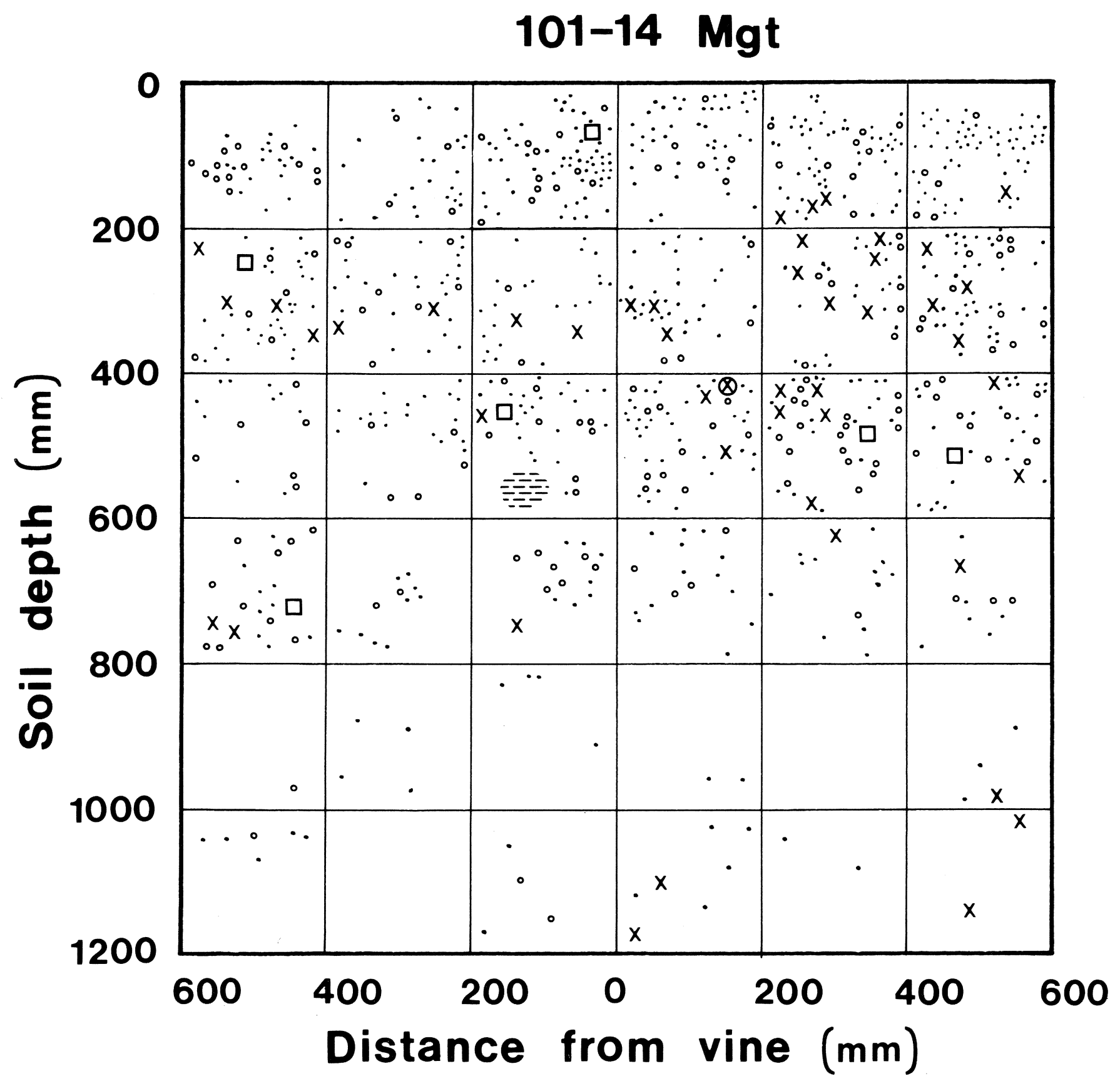

FIGURE 2a

Root distribution of 101-14 Mgt in an Oakleaf soil. Grid System $200 \times 200 \mathrm{~mm} . \cdot=<0,5 \mathrm{~mm}, \circ=0,5-2,0 \mathrm{~mm}, \mathrm{X}=2,0-5,0$ $\mathrm{mm}, \square=5,0-10 \mathrm{~mm}, \otimes=>10 \mathrm{~mm}$.

Relative to other rootstocks [for example, 101-14 Mgt (Fig. 2a)], US 16-13-23 (Fig. 2b) had a greater number of fine roots in the deeper soil layers $(>600 \mathrm{~mm}$ ) (Table 5). Although this should be indicative of the better utilization of the available soil volume, it also implies that US 16-13$23 \mathrm{had}$ a higher percentage of these roots in the more saline subsoil (Table 5). The total root number of this rootstock, however, was relatively low (Table 6). These factors could account for the low pruning mass of this rootstock found in this study (Table 6) and with Colombard grafted onto it (Southey \& Jooste, 1991). 


\section{US $16-13-23$}

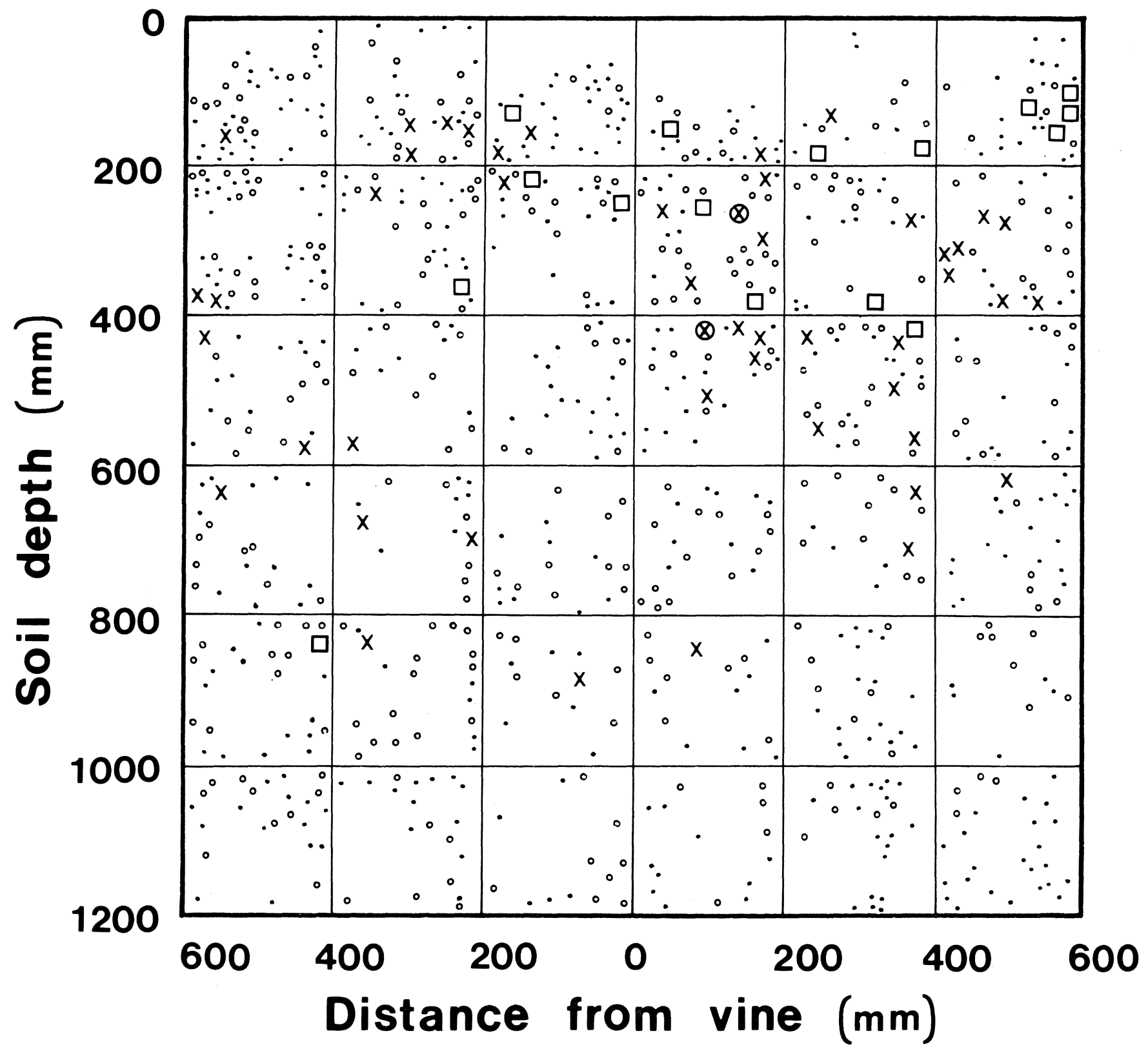

FIGURE $2 b$

Root distribution of US 16-13-23 in an Oakleaf soil. Grid System $200 \times 200 \mathrm{~mm} . \cdot=<0,5 \mathrm{~mm}, \circ=0,5-2,0 \mathrm{~mm}, \mathrm{X}=2,0-5,0$ $\mathrm{mm}, \square=5,0-10 \mathrm{~mm}, \otimes=>10 \mathrm{~mm}$.

Root number: A highly significant positive correlation was found between the pruning mass and the root number per $\mathrm{m}^{2}$ (root density) $(\mathrm{r}=0,85)$. The highest root densities were found with the rootstocks 216/3 Castel and 1103 Paulsen and these cultivars had higher pruning masses than cultivars such as Grezot 1, US 16-13-23 and Ramsey, which had relatively low root densities (Table 6). In other root studies (Richards, 1983; Van Zyl \& Van Huyssteen, 1984; Archer, Swanepoel \& Strauss, 1988; Southey \& Archer, 1988; Swanepoel \& Southey, 1989), the aboveground and subterranean growth of the grapevine were also found to be in balance. 
TABLE 6

Root density and pruning mass of 10 rootstock cultivars in an Oakleaf soil in the Robertson district.

\begin{tabular}{|l|c|c|}
\hline $\begin{array}{l}\text { Rootstock } \\
\text { Cultivar }\end{array}$ & $\begin{array}{c}\text { Root } \\
\text { Density } \\
\text { (Root number/m }{ }^{2} \text { ) }\end{array}$ & $\begin{array}{c}\text { Pruning } \\
\text { Mass } \\
\text { (kg/vine) }\end{array}$ \\
\hline 216/3 Castel & 1040 & 2,1 \\
1103 Paulsen & 882 & 1,8 \\
99 Richter & 766 & 1,5 \\
140 Ruggeri & 704 & 1,6 \\
110 Richter & 700 & 1,6 \\
13/5 E.V.E. Jerex & 650 & 1,6 \\
101-14 Mgt & 600 & 1,5 \\
Grezot 1 & 598 & 0,9 \\
US 16-13-23 & 594 & 0,8 \\
Ramsey & 485 & 0,8 \\
\hline Regression Coefficient
\end{tabular}

The spatial root distribution of rootstocks such as $216 / 3$ Castel and 1103 Paulsen, which grew relatively vigorously, was similar to that of less vigorous rootstocks. Therefore, the increase in the size of the root system was not the result of the utilization of a larger soil volume but rather the consequence of a greater root density.

However, other rootstocks, such as 101-14 Mgt, grew relatively vigorously but had low root densities. This suggests that although the above-ground and subterranean growth are in balance, the former is not solely a function of root density and differences in root efficiency could account for this discrepancy.

\section{CONCLUSIONS}

The growth of all the grapevine roots, and in particular the fine roots, decreased with decreasing electrical resistance within the soil profiles. Consequently, spatial root distributions of the rootstocks studied did not differ markedly and non were capable of effectively colonising the deeper, more saline layers.

Although it has been found that favourable conditions in the topsoil as such do not lead to shallow rooting, the results of this study support the concept that shallower rooting is enhanced when vertical root growth is restricted either physically or chemically. This appears to be particularly true with respect to the finer roots. Daulta \& Chauhan (1980) found that the size of the zone in which the majority of the roots were found was affected by the cultivar. The results of this study, however, suggest that the size and location of this zone is more dependent on the characteristics of the soil than the rootstock cultivar as such.

The root density, however, differed between rootstocks, ranging from 1040 roots per $\mathrm{m}^{2}$ for $216 / 3$ Castel to 485 per $\mathrm{m}^{2}$ for Ramsey. Using this as a measure of extent of utilisation of the available soil volume, 216/3 Castel, 1103 Paulsen and 99 Richter were the most effective. Although the above-ground and subterranean growth were found to be in balance, differences in the rates of uptake of nutrients and toxic ions between different rootstocks are widely reported in the literature and, therefore, root distribution alone cannot account for differences in the adaptation of rootstocks to salinity. The extent to which the uptake of nutrients and toxic ions was affected by the rootstocks and the effects of differences in root distribution on the physiology of the vine are currently being investigated.

\section{LITERATURE CITED}

ARBABZADEH, F. \& DUTT, G., 1987. Salt tolerance of grape rootstocks under greenhouse conditions. Am. J. Enol. Vitic. 38, 95-99.

ARCHER, E. \& STRAUSS, H.C., 1985. Effect of plant density on root distribution of three-year-old grafted 99 Richter grapevines. S. Afr. J. Enol. Vitic. 6, 25-30.

ARCHER, E., SWANEPOEL, J.J. \& STRAUSS, H.C., 1988. Effect of plant spacing and trellising systems on grapevine root distribution. In: VAN ZYL, J.L. (comp.). The grapevine root and its environment, Tech. Comm. 215. Dept. Agric. Developm., Private Bag X116, 0001 Pretoria, Republic of South Africa. pp. 74-87.

BLAKE, J.D.F., 1965. Bulk density. In: BLACK, C.L., EVANS, D.D., WHITE, J.L., ENSMINGER, L.E. \& CLARK, F.E. (eds.). Methods of soil analysis. Agron. Series 9, Part 1. pp. 374-390.

BÖHM, W., 1979. Methods of studying root systems. Ecological Studies. Vol. 33. Springer Verlag, Berlin, Germany.

BRANAS, J., 1974. Viticulture. Dehan, Montpellier, France.

CHAMPAGNOL, F., 1984. Elements de physiologie de la vigne et de viticulture generale. Dehan, Montpellier, France.

CONRADIE, W.J., 1983. Liming and choice of rootstocks as cultural techniques for vines in acid soils. S. Afr. J. Enol. Vitic. 4, 39-44.

DAULTA, B.S. \& CHAUHAN, K.S., 1980. Varietal variations in root growth of some grape cultivars. Proq. Hort. 12, 37-39.

DE KLERK, C.A., 1970. Biologie van die wingerdfilloksera Phylloxera vitifoliae Fitch. (Homoptera: Phylloxeridae) in Suid-Afrika. M.Sc. thesis, University of Stellenbosch, 7600 Stellenbosch, Republic of South Africa.

DE KLERK, C.A., 1978. Morphology and taxonomy of the South African species of the genus Margarodes (Hemiptera: Margarodidae), with detailed studies on the biology of two vine infesting species. Ph.D. dissertation, University of Stellenbosch, 7600 Stellenbosch, Republic of South Africa.

DE KLERK, C.A. \& LOUBSER, J.T., 1988. Relationship between grapevine roots and soil-borne pests. In: VAN ZYL, J.L. (comp.). The grapevine root and its environment. Tech. Comm. 215. Dept. Agric. Developm., Private Bag X116, 0001 Pretoria, Republic of South Africa. pp. 88-105.

DOWNTON, W.J.S., 1985. Growth and mineral composition of the Sultana grapevine as influenced by salinity and rootstock. Aust. J. agric. Res. 36, 425-434.

GALET, P., 1979. A practical ampelography. Grapevine identification. Cornell University Press, Ithaca, New York, USA.

GROOT OBBINK, J. \& ALEXANDER, D. McE., 1973. Response of six grapevine cultivars to a range of chloride concentrations. Am. J. Enol. Vitic. 24, 65-68.

KRIEL, G. le R., 1985. Die keuse van onderstokke. Wynboer Tegnies 12, $11-15$.

LOUBSER, J.T., 1985. A modified sieving-sedimentation method for extracting nematodes from soil. Hort. Sci. 3, 23-25.

MACVICAR, C.N. \& SOIL SURVEY STAFF., 1977. Soil classification A binomial system for South Africa. Scientific Pamphlet 390. Dept Agric. Developm., Private Bag X116, 0001 Pretoria, Republic of South Africa.

MARAIS, P.G., 1983. Phytophthora cinnamomi root rot of grapevines in South Africa. Ph.D. dissertation, University of Stellenbosch, 7600 Stellenbosch, Republic of South Africa.

MARCELIN, H., 1974. La vigne dans le sols du Roussillon. Progrés agric vitic. 91, 548-555.

PERRY, R.L., LYDA, S.D. \& BOWEN, H.H., 1983. Root distribution of four Vitis cultivars. Plant and Soil 71, 63-74. 
PONGRACZ, D.P., 1983. Rootstocks for grape-vines. David Philip Publisher, Cape Town, Republic of South Africa.

RANGELOV, B., TODOROV, K.H. \& GEORGIEV, Z., 1981. Effect of spacing and scion cultivar on root system development in grapevine. Grad. Loz. Nauka 18, 82-90. In: Hort. Abstr. (1982) 52, 7828.

RICHARDS, D., 1983. The grape root system. Hort. Rev. 5, 127-168.

RICHARDS, L.A. \& U.S. SALINITY LABORATORY STAFF., 1954. Diagnosis and improvement of saline and alkaline soils. USDA Handbook no. 60. U.S. Govt. Printing Office, Washington D.C., USA.

SAAYMAN, D., 1981. Wingerdvoeding. In: BURGER, J. \& DEIST, J. (eds.).Wingerdbou in Suid-Afrika. Viticultural and Oenological Research Institute, Private Bag X5026, 7600 Stellenbosch, Republic of South Africa. pp. 343-383.

SAAYMAN, D., 1982. Soil preparation studies: II. The effect of depth and method of soil preparation and of organic material on the performance of Vitis vinifera (var. Colombar) on a Clovelly/Hutton soil. S. Afr. J. Enol. Vitic. 3, 61-74.

SAAYMAN, D. \& VAN HUYSSTEEN, L., 1980. Soil preparation studies: I. The effect of depth and method of soil preparation and of organic material on the performance of Vitis vinifera (var. Chenin Blanc) on a Hutton/Sterkspruit soil. S. Afr. J. Enol. Vitic. 1, 107-121.

SOUTHEY, J.M. \& ARCHER, E., 1988. The effect of the rootstock cultivar on grapevine root distribution and density. In: VAN ZYL, J.L. (comp.). The grapevine root and its environment. Tech. Comm. 215.

Dept. Agric. Developm., Private Bag X116, 0001 Pretoria, Republic of South Africa. pp. 57-73.

SOUTHEY, J.M. \& JOOSTE, J.H., 1991. The effect of grapevine rootstock on the performance of Vitis vinifera L. (cv. Colombard) on a relatively saline soil. S. Afr. J. Enol. Vitic. 12, 32-41.

SOYER, J.P., DELAS, J., MOLOT, C., ANDRAL, P. \& CASTERAN, P., 1984. Techniques d'entretien du sol en vignoble Bordelais. Consequences sur la vigne (production, vigueur, enracinement, nutrition) et sur le sol apres 20 ans d'experimentation. Progrés agric. vitic. 101,
315-320.

SWANEPOEL, J.J. \& SOUTHEY, J.M., 1989. The influence of rootstock on the rooting pattern of the grapevine. S. Afr., J. Enol. Vitic. 10, 23-28.

VAN DER WESTHUIZEN, J.H., 1980. The effect of black plastic mulch on growth, production and root development of Chenin Blanc vines under dryland conditions. S. Afr. J. Enol. Vitic. 1, 1-6.

VAN HUYSSTEEN, L., 1988a. Soil preparation and grapevine root distribution - a qualitative and quantitative assessment. In: VAN ZYL, J.L. (comp.). The grapevine root and its environment. Tech. Comm. 215 Dept. Agric. Developm., Private Bag X116, 0001 Pretoria, Republic of South Africa. pp. 1-15.

VAN HUYSSTEEN, L., 1988b. Grapevine root growth in response to soil tillage and root pruning practices. In: VAN ZYL, J.L. (comp.). The grapevine root and tis environment. Tech. Comm. 215. Dept. Agric Developm., Private Bag X116, 0001 Pretoria, Republic of South Africa. pp. 44-56.

VAN ZYL, J.L., 1984. Interrelationships among soil water regime, irrigation and water stress in the grapevine (Vitis vinifera L.). Ph.D. dissertation, University of Stellenbosch, 7600 Stellenbosch, Republic of South Africa.

VAN ZYL, J.L. \& VAN HUYSSTEEN, L., 1984. Soil and water management for optimum grape yield and quality under conditions of limited or no irrigation. In: Proc. Fifth Industry Technical Conference, 29 Nov. - 1 Dec. 1983. University of Western Australia, Perth, Australia pp. 25-66.

WEST, D.W. \& TAYLOR, J.A., 1984. Response of six grape cultivars to the combined effects of high salinity and rootzone waterlogging. $J$ Amer. Soc. Hort. Sci. 109, 844-851.

ZEEMAN, A.S., 1981. Oplei. In: BURGER, J. \& DEIST, J. (eds.) Wingerdbou in Suid-Afrika. Viticultural and Oenological Research Institute, Private Bag X5026, 7600 Stellenbosch, Republic of South Africa. pp. 185-201. 